\title{
Structural Study of Microporous Xerogels Prepared by Polycondensation of Pyrogallol with Formaldehyde
}

\author{
Rebeh Moussaoui ${ }^{a}$, Mongi ben mosbah ${ }^{\mathrm{a}}$, Younes Moussaoui ${ }^{\mathrm{b} *}$ and Elimame Elaloui ${ }^{\mathrm{a}}$ \\ ${ }^{a}$ Material, Environment and Energy Laboratory, (06/UR/12-01) Science Faculty of Gafsa, Gafsa University, \\ Tunisia. \\ limam_aloui@yahoo.fr \\ ${ }^{\mathrm{b}}$ Physical Organic Chemistry Laboratory, (UR11-ES74) Science Faculty of Sfax, Sfax University, Tunisia. \\ y.moussaoui2@gmx.fr \\ * Corresponding author: E-mail address: y.moussaoui2@gmx.fr
}

\section{ABSTRACT}

Microporous xerogels were prepared by polycondensation of pyrogallol with formaldehyde catalyzed by perchloric acid in aqueous medium. The samples were characterized by FTIR absorption spectra. The micro-porosity and the specific surface area are characterized by nitrogen adsorption - desorption isotherms. The obtained characteristics depend on the conditions of polycondensation.

Keywords: carbon xerogel; polycondensation; pyrogallol; formaldehyde; adsorption; desorption

\section{Council for Innovative Research}

Peer Review Research Publishing System

\section{Journal: Journal of Advances in Chemistry}

Vol. 6, No. 1

editor@cirworld.com

www.cirworld.com, member.cirworld.com 


\section{INTRODUCTION}

Porous carbon materials (or activated carbon) are known and used by man for centuries [1]. They are used in many applications such as adsorbents for gas separation [2,3], catalyst support [4-10], electrode for fuel cell or super capacitor $[11,12]$. The application of these activated carbons is related to their porous texture, surface properties and composition of the original material. The carbonaceous materials are in fact produced by heat treatment of natural organic materials. Which gives materials with variable properties and nothing guarantees the consistency of texture, surface properties, mechanical strength or composition of charcoal. That is why the development of carbon materials turned to the chemical synthesis of precursor materials for carbon. Thereby producing carbons are completely controlled and reproducible properties. In the early $90 \mathrm{~s}$, Pekala has synthesized resorcinol-formaldehyde resins in a solvent to prepare porous materials [13-15]. Subsequently, numerous studies have vested in the preparation of polymers and activated carbon precursors by condensation of hydroxylated benzene (phenol, catechol, 4-methylcatechol, m-cresol, hydroquinone, phloroglucinol, resorcinol, ...) with aldehyde (formaldehyde, furfural, ...) [16-25].

Thus, the synthesis of organic gels allows obtaining very pure carbon materials and texture controlled and reproducible. However, the synthesis methods have many disadvantages and are difficult to apply in the industrial level. In fact, several parameters that can affect the properties of the obtained material such as the nature of the solvent, the organic reactants, the catalyst and the drying mode. In addition, the polycondensation of pyrogallol with formaldehyde seems to be very little studied $[26,27]$. We report here the preparation of xerogels of this polymer by the reaction carried out according to the solgel technique.

\section{EXPRIMENTAL}

\subsection{Pyrogallol-formaldehyde resin}

Pyrogallol $(0.11 \mathrm{~mol})$ was reacted at room temperature with formaldehyde $(0.33 \mathrm{~mol})$ in $60 \mathrm{~mL}$ of water, in the presence of perchloric acid $\mathrm{HClO}_{4}$ as catalyst. And 4 samples were prepared by varying the pyrogallol / catalyst molar ratio (Table 1).

Table 1. Preparation of samples.

\begin{tabular}{|c|c|c|c|c|}
\hline Sample & PF-2 & PF-3 & PF-4 & PF-5 \\
\hline $\mathrm{Pyr} / \mathrm{HClO}_{4}$ & 2 & 3 & 4 & 5 \\
\hline
\end{tabular}

After gelation, the obtained sample was aged by placing it in a water bath to stabilize its temperature at $50^{\circ} \mathrm{C}$ for $48 \mathrm{~h}$. The gel is then demolded and rinsed or not before drying it in an oven for five successive week intervals at 60, 80, 100, 120, and finally at $150^{\circ} \mathrm{C}$.

\subsection{Characterization}

The $\mathrm{N}_{2}$ adsorption isotherms were recorded at liquid nitrogen temperature $(77 \mathrm{~K})$ on a Micromeritics Autochem ASAP 2020 V3.00 H unit. The surface areas were calculated with the Brunauer-Emmet-Teller (BET) calculation method, using the adsorption data within the P/P0 range from 0.05 to 0.35 . The Barret-Joyner-Halenda (BJH) method was used to obtain the pore size distribution.

The IR spectra were recorded in $\mathrm{KBr}$ with a JASCO FT-IR-420 spectrometer, with a precision of $\pm 2 \mathrm{~cm}^{-1}$ in the range $500-4000 \mathrm{~cm}^{-1}$.

\section{RESULTS AND DISCUSSION}

\subsection{Measurement of gelation time}

The measurement of gelation time gives the results shown in Table 2.

Table 2. Variation of gelation time.

\begin{tabular}{|c|c|c|c|c|}
\hline Sample & PF-2 & PF-3 & PF-4 & PF-5 \\
\hline $\mathrm{Pyr} / \mathrm{HClO}_{4}$ & 2 & 3 & 4 & 5 \\
\hline $\operatorname{tg}(\min )$ & 12 & 20 & 40 & 50 \\
\hline
\end{tabular}

The gelation time increases with the $\mathrm{Pyr} / \mathrm{HClO}$ ratio. 


\subsection{Nitrogen adsorption - desorption isotherms}

The adsorption-desorption isotherms of nitrogen at $77 \mathrm{~K}$ on xerogels prepared by polycondensation of pyrogallol with formaldehyde catalyzed by perchloric acid in aqueous media with different $\mathrm{Pyr} / \mathrm{HClO}_{4}$ ratios are shown in figure1. The isotherms (figure 1) show a type I isotherm indicating that samples are microporous [28-31]. Textural characteristics of PF obtained by calcination at $150^{\circ} \mathrm{C}$ are given in Table 3 .

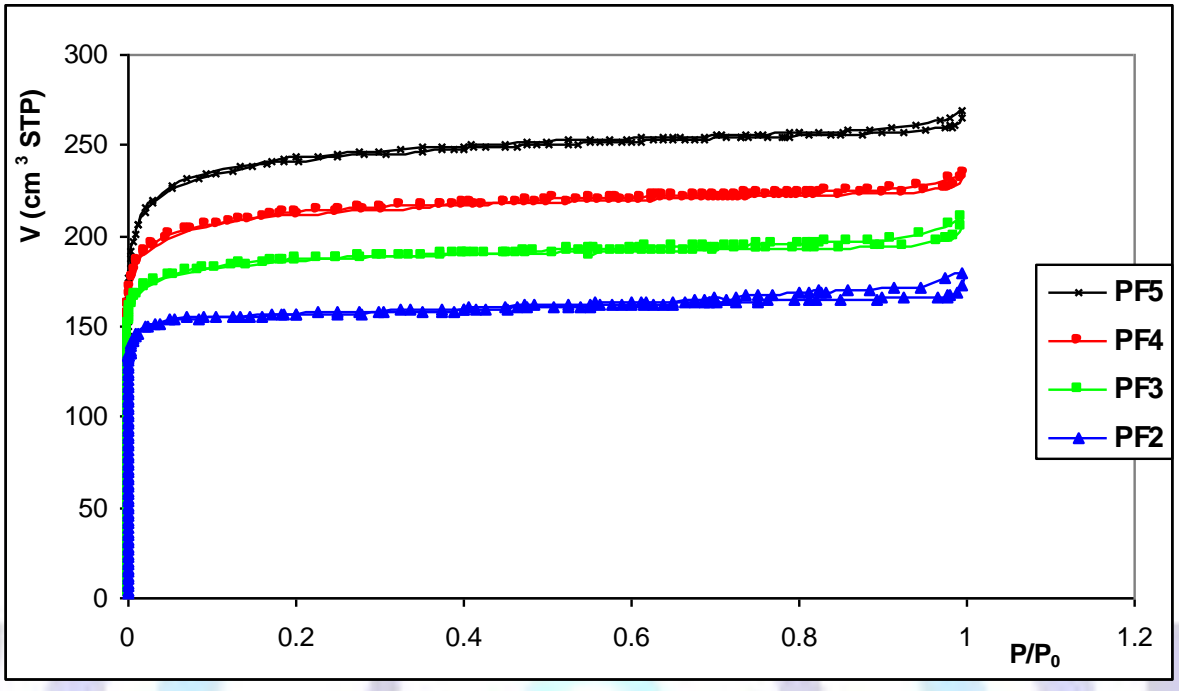

Fig 1: Nitrogen adsorption-desorption isotherms of the samples PF2, PF3, PF4 and PF5.

Table 3. Variation of gelation time

\begin{tabular}{|c|c|c|c|c|c|c|c|}
\hline Sample & $\begin{array}{l}S(B E T) \\
\left(\mathrm{m}^{2} \mathrm{~g}^{-1}\right)\end{array}$ & $\begin{array}{c}\text { S pores } \\
2<d<500 \mathrm{~nm}\end{array}$ & $\begin{array}{c}S \mu p o r e s \\
\left(m^{2} g^{-1}\right)\end{array}$ & $\begin{array}{l}\text { V pores } \\
\left(\mathrm{cm}^{3} \mathrm{~g}^{-1}\right)\end{array}$ & $\begin{array}{c}V \text { pores } \\
2<d<500 \mathrm{~nm}\end{array}$ & $\begin{array}{l}V \text { upores } \\
\left(\mathrm{cm}^{3} \mathrm{~g}^{-1}\right)\end{array}$ & $\begin{array}{l}\text { D pores } \\
(\mathrm{nm})\end{array}$ \\
\hline PF2 & 699.8 & 25.2 & 674.6 & 0.352 & 0.035 & 0.318 & 2.052 \\
\hline PF3 & 628.0 & 153.7 & 474.3 & 0.307 & 0.076 & 0.231 & 1.957 \\
\hline $\begin{array}{l}\text { PF4 } \\
\end{array}$ & 641.9 & 94.8 & 547.1 & 0.350 & 0.075 & 0.275 & 2.185 \\
\hline PF5 & 729.92 & 154.12 & 575.8 & 0.401 & 0.107 & 0.294 & 2.220 \\
\hline
\end{tabular}

The BET surface areas are higher than those obtained by Job et al. by polymerization of resorcinol with formaldehyde [32,33]. Else Hirotomo Nishihara et al. obtained resorcinol-formaldehyde gels micro, meso and macroporous [34]. The microporous specific surface area varies from 474 to $674 \mathrm{~m}^{2} / \mathrm{g}$, with micropore volumes between 0.231 and $0.318 \mathrm{~m}^{2} / \mathrm{g}$ (table 3$)$.

\subsection{FTIR spectroscopy}

The IR Transmission spectra of PF polymers was first compared with those of their counterparts RF (figure 2) prepared by polycondensation of resorcinol with formaldehyde in identical conditions. The IR transmission spectra of RF and PF samples are very similar. We found substantially the same frequencies of vibration excepting a shoulder that appears around $1685 \mathrm{~cm}^{-1}$ in the spectrum of the PF resin (figure 2). 


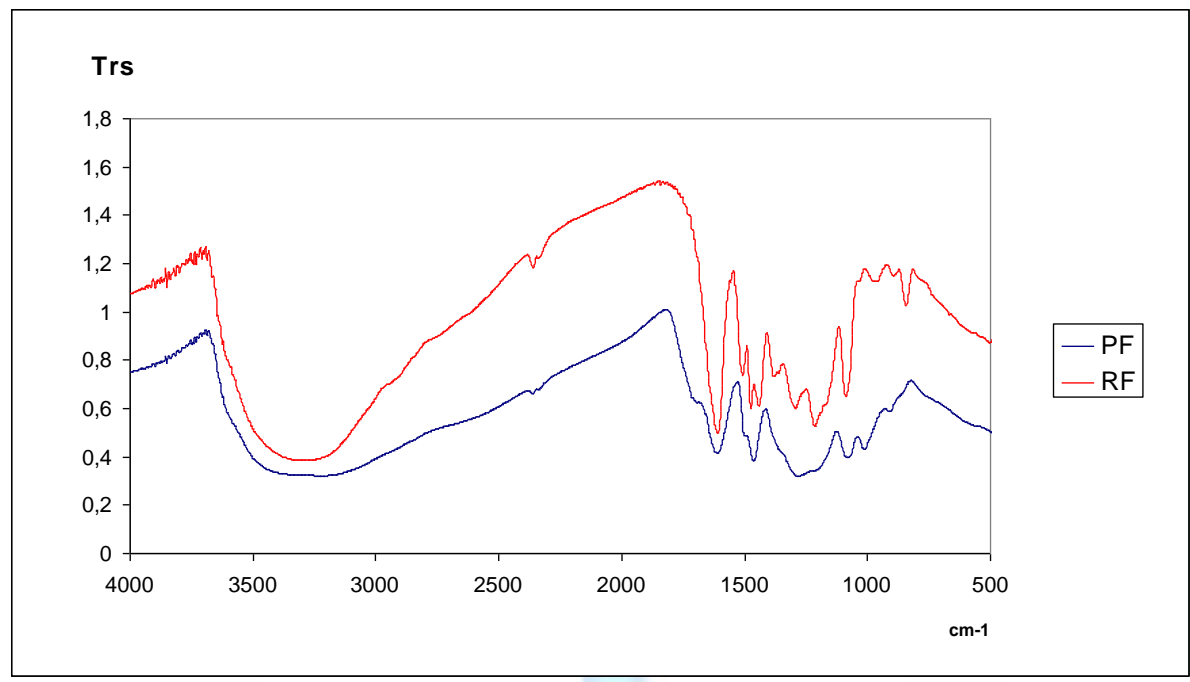

Figure 2. FTIR spectra of the PF and RF samples.

When the product obtained by condensation is not washed, $\mathrm{HClO}_{4}$ remains trapped in the polymer (figure 3 and 4). We distinguished at $625 \mathrm{~cm}^{-1}$ a thin strip due to $\mathrm{HClO}_{4}$, indeed $\mathrm{ClO}_{4}{ }^{-}$ion is characterized by a v4 band found between 627 and $645 \mathrm{~cm}^{-1}$ [35]. These PF evolve by calcination and their spectra are shown in figure 5 . They are identical to each other within each series.

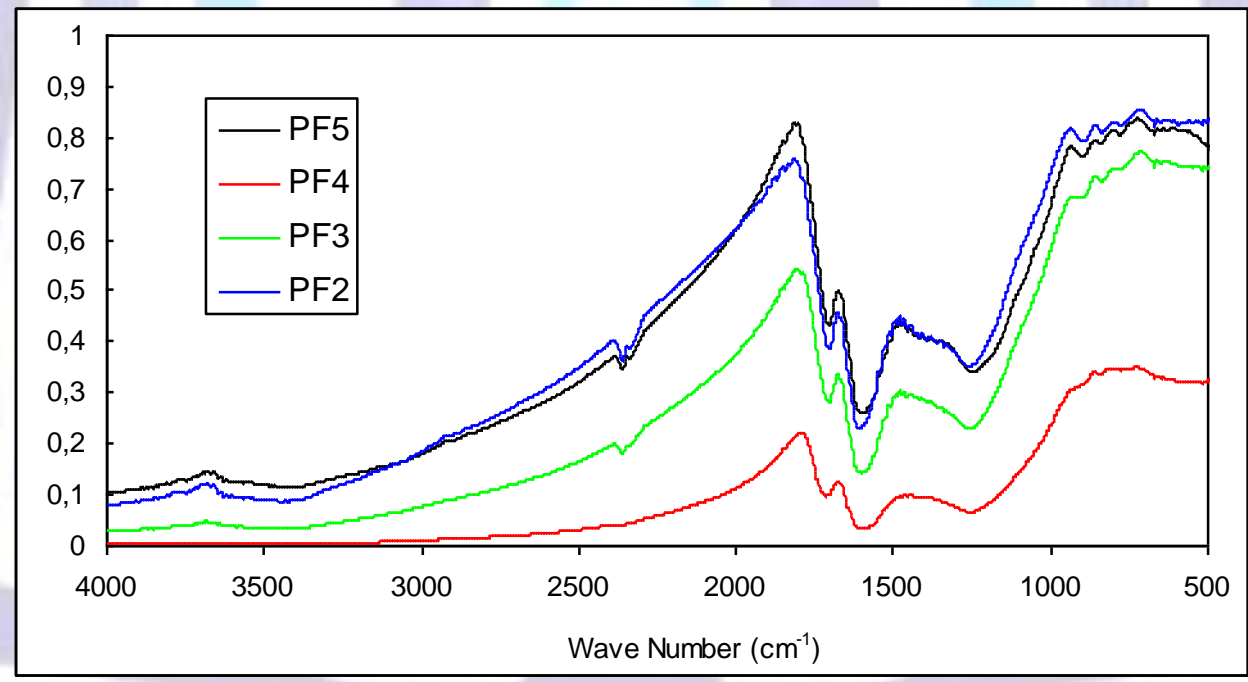

Figure 3. FTIR spectra of the washed PF samples. 


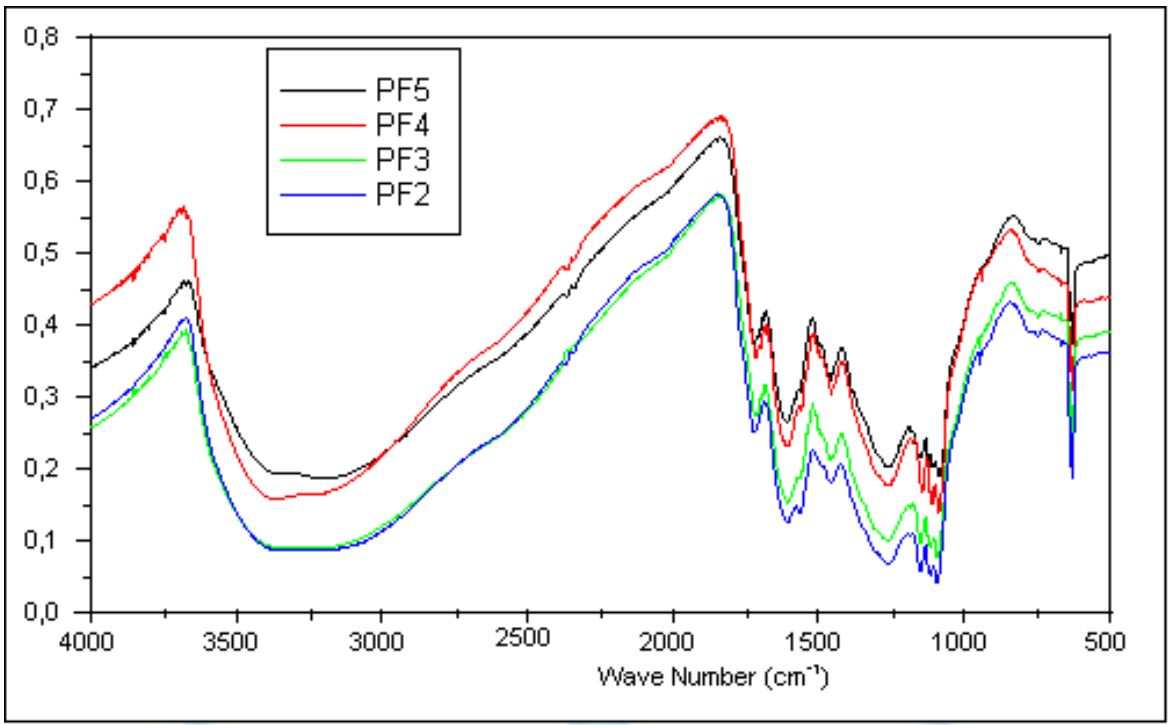

Figure 4. FTIR spectra of the unwashed PF samples.

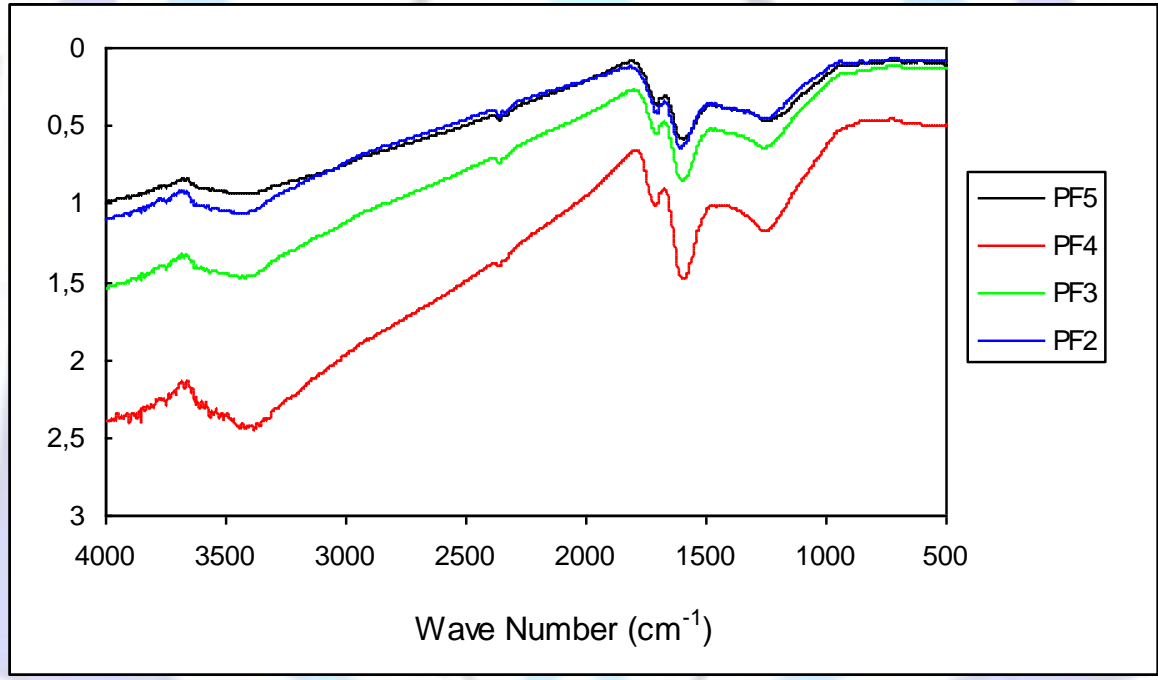

Figure 5. FTIR spectra of the PF samples after calcinations at $150^{\circ} \mathrm{C}$

\section{CONCLUSION}

Organic xerogel compounds were prepared by sol-gel process from pyrogallol-formaldehyde. The polymerisation of pyrogallol and formaldehyde was performed in water using perchoric acid as catalyst. The stoichiometric $\mathrm{Pyr} / \mathrm{HClO}_{4}$ molar ratios were 2,3,4 and 5 .

\section{ACKNOWLEDGEMENTS}

We greatly acknowledge financial support of the Ministry of Higher Education and Scientific Research of Tunisia

\section{REFERENCES}

[1] Derbyshire, F., Jagtoyen, M. and Thwaites M. Activated carbons-Production and applications. In: J.W. Patrick (Ed.), Porosity in carbons, Wiley, UK, (1995) p. 227.

[2] Yamamoto, T., Endo, A., Ohmori, T. and Nakaiwa, M., Carbon 42 (2004) 1671-1676.

[3] Sircar, S., Golden, T. C. and Rao, M. B., Carbon 34 (1996) 1-12.

[4] Rodríguez-Reinoso, F. Carbon as a catalyst support. In: J.W. Patrick (Ed.), Porosity in carbons, Wiley, UK, (1995) p. 253.

[5] Job, N., Heinrichs, B., Ferauche, F., Noville, F., Marien, J. and Pirard, J. P., Catal. Today 102-103 (2005) $234-241$. 
[6] Job, N., Pereira, M. F. R., Lambert, S., Cabiac, A., Delahay, G., Colomer, J. F., Marien, J., Figueiredo, J. L. and Pirard, J. P., J. Catal. 240 (2006) 160-171.

[7] Sanchez-Polo, M., Rivera-Utrilla, J. and Von Gunten, U., Wat. Res. 40 (2006) 3375-3384.

[8] Padilla-Serrano, M. N., Maldonado-Hodar, F.J. and Moreno-Castilla, C., Appl. Catal. B-Environ. 61 (2005) $253-258$.

[9] Moreno-Castilla, C. and Maldonado-Hodar, F. J., Carbon 43 (2005) 455-465.

[10] Tonanon, N. and Wareenin, Y., J. Non-Cryst. Solids 352 (2006) 5683-5686.

[11] Li, W., Reichenauer, G. and Fricke, J., Carbon 40 (2002) 2955-2959.

[12] Probstle, H., Schmitt, C. and Frick, J., J. Power Sources 105 (2002) 87.

[13] Pekala, R. W. and Kong, F. M., Rev. Phys. Appl. 24 (C4) (1989) 33.

[14] Pekala, R. W., J. Mat. Sci. 24 (1989) 3221-3227.

[15] Pekala, R.W., Alviso, C.T. and LeMay, J. D. Organic aerogels: a new type of ultrastructured polymer. In: L.L. Hench, J.K. West (Eds.), Chemical processing of advanced materials, Wiley, New York, 1992, p. 671.

[16] Wei, W., Hu, H., Qin, G., You, L. and Chen, G., Carbon 42 (2004) 679-681.

[17] Albert, D. F., Andrews, G. R., Mendenhall, R. S. and Bruno, J. W., J. Non-Cryst. Solids 296 (2001) 1-9.

[18] Tonanon, N., Siyasukh, A., Tanthapanichakoon, W., Nishihara, H., Mukai, S. R. and Tamon, H., Carbon 43 (2005) 525-531.

[19] Saliger, R., Bock, V., Petrcevic, R., Tillostson, T., Geis, S. and Fricke, J., J. Non-Cryst. Solids 221 (1997) 144-150.

[20] Leonard, A., Blacher, S., Crine, M. and Jomaa, W., J. Non-Cryst. Solids 354 (2008) 831-838.

[21] Bock, V., Emmerling, A. and Fricke, J., J. Non-Cryst. Solids 225 (2005) 69-73.

[22] Leonard, A., Job, N., Blacher, S., Pirard, J. P., Crine, M. and Jomaa, W., Carbon 43 (2005) 1808-1811.

[23] Yamamoto, Y., Sugimoto, T., Suzuki, T., Mukai, S. R. and Tamon, H., Carbon 40 (2002) 1345.

[24] Hamamoto, K., Kawakita, H., Ohto, K. and Inoue, K., Reactive \& Functional Polymers 69 (2009) 694-697.

[25] Moussaoui, Y., Elaloui, E. and Ben Salem, R., C. R. Chimie 15 (2012) 493-498.

[26] El Mir, L., Kraiem, S., Bengagi, M., Elaloui, E., Ouederni, A. and Alaya, S., Physica B 395 (2007) 104-110.

[27] Krause, T., Gruner, M., Kuckling, D. and Habicher, W. D., Tetrahedron Lett., 45 (2004) 9635-9639.

[28] Rouquerol, F., Rouquerol, J., Sing, K. Adsorption by powders and porous solids, principles, methodology and applications. Academic Press, New York, 1999.

[29] Mirzaeian, M. and Hall, P. J., J. Mater. Sci., 44 (2009) 2705-2713.

[30] Lecloux, A. J. in: Anderson, J. R., Boudart, M. (Eds.), Catalysis, Science and Technology, Vol. 2, Springer, Berlin, 1981 , p. 171.

[31] Brunauer, B., Emmett, P. H. and Teller, E., J. Am. Chem. Soc., 60 (1938) 309.

[32] Job, N., Pirard, R., Marien, J. and Pirard, J.-P., Carbon 42 (2004) 619-628.

[33] Leonard, A., Job, N., Jomaa, W., Pirard, J.-P., Crine, M. and Puiggali, J.-R., Récents Progrès en Génie des Procédés, 92, (2005) 1-8.

[34] Nishihara, H., Mukai, S. R. and Tamon, H., Carbon 42 (2004) 899-901.

[35] Ross, S. D. Inorganic Infrared and Raman spectra, McGraw-Hill, London, 1972. 